\title{
15-84-5 血管内皮機能検査システムの開発
}

Study on automatic FMD (flow-mediated dilatation) measurement system

O竹内涉，山口喬弘，吉田大樹，廣松馨，佐久間一郎，小林英津子,

土肥健純*, 宮田哲郎 $* *$, 重松宏**, 大内尉義**, 吉栖正生***

東京大学大学院新領域創成科学研究科, $*$ 東京大学大学院情報理工学系研究科,

**東京大学大学院医学系研究科, ***広島大学大学院医歯薬学総合研究科

W.TAKEUCHI, T.YAMAGUCHI, D.YOSHIDA, K. HIROMATSU, I. SAKUMA, E. KOBAYASHI,

T. DOHI ${ }^{\star}$, T. MTYATA ${ }^{* \star}$, H. SIGEMATSU ${ }^{\star *}$, Y. OUCHI ${ }^{\star *}$, M. YOSHIZUMI $^{\star \star \star}$

Graduate School of Frontier Sciences, the Univ. of Tokyo,

${ }^{*}$ Graduate School of Information Science and Technology, the Univ. of Tokyo

${ }^{\star \star}$ Graduate School of Medicine, the Univ. of Tokyo, ${ }^{* * *}$ Graduate School of Biomedical Sciences, Hiroshima Univ.

1. 背景

現在心臟の冠動脈疾患や脳血管障害のリスクファクタ 一と考えられている血管内皮機能低下の評価法として血 管内皮機能検查法が考案されている.この検査法梳、下腕 部を 5 分間駆血し, 駆血解除後の上腕動脈の安静時に対す る血管径増加率(\%FMD)を指標としており，以下の式で表 される ${ }^{1)}$.

$$
\begin{gathered}
\% \mathrm{FMD}=\frac{D_{\max }-D_{p m e}}{D_{m}} \times 100 \\
D_{\max }: \text { 最大拡張血管径 } D_{m e r}: \text { 安静時血管径 }
\end{gathered}
$$

この生理学的現象は，血管内皮細胞が NO 等の内皮依存 弛緩因子(EDRF)を放出することで血管内のシェアストレ スを一定に保つ働きを有することに因り，駆血解除後的 30 秒で最大血管拡張がみられる(Fig. 1). 急激な血流量の 增加はシェアストレスの增加につながり，血管拡張の要因 となる. \%FMD 住健常者で 10\%超に対し，動脈硬化危険 因子度の高い患者では 3\%程度にとどまるといわれている。 現在は，医師がプローブ操作及び血管径計測を行っている が, 計測時間が長い, 検查に熟練を要する, 検査結果にほ らつきが生じる等の問題点が指摘されている2).そこで本 研究では, これらの問題点を解決するため, 画像処理とブ ローブ自動位置決めを利用した血管内皮機能検查自動化 システム(FMD Automatic Measurement System : FMD-AMS)の開発を行った。

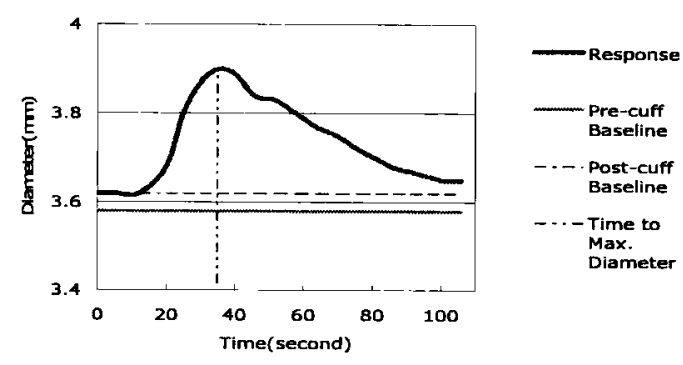

Fig. 1 Vessel diameter to time in dilatation

2. 万法

\section{1.システム概要}

Fig.2 に険查システムの構成図を示寸，PC 部は超音波 診断装置から得られる画像に対して血管径抽出などの処 理を行い, その結果に基づくマニピュレータ位置の計算及 びモータに対する制御信号の送信を行う.マニピュレータ 部は超音波プローブを保持・位置決めを行う. マニピュレ 一タはマニュアルで大まかな位置決めをおこない, その後， 回転 1 自由度, 並進 2 自由度でモ一夕駆動に上る位置決め をおこなう(Fig. 3). GUI 機能を付加したソフトウェアは Visual C++を用いて作成した. また超音波画像診断装置で は $11 \mathrm{MHz}$ のプローブを使用した。

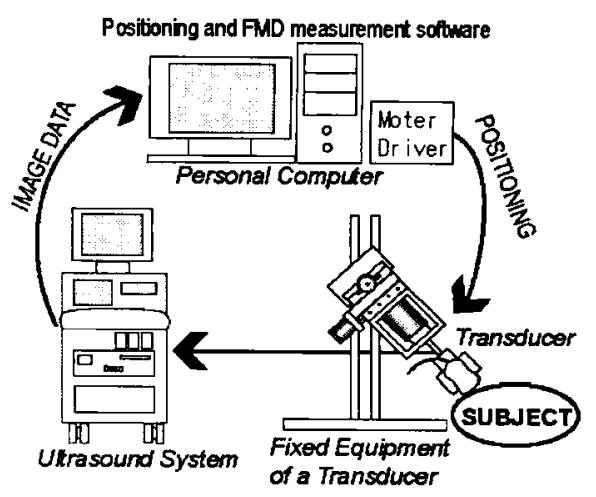

Fig. 2 FMD-AMS

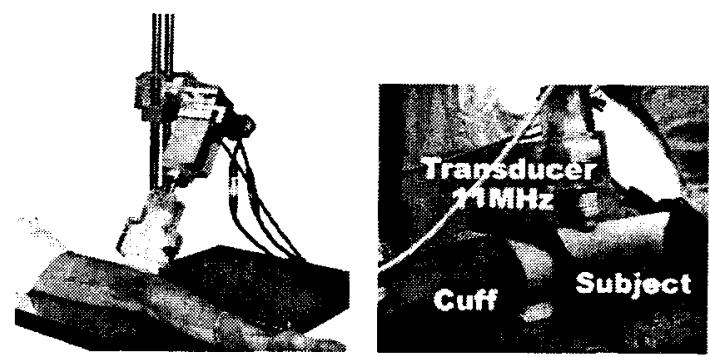

Fig. 3 Probe positioning manipulator

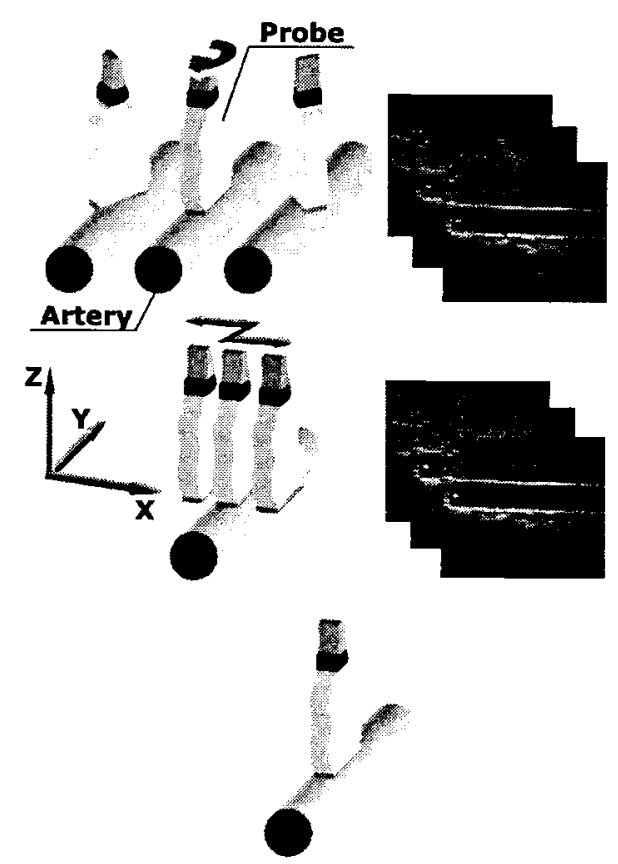

Fig. 4 Procedure for positioning the probe 


\section{2.計測手順}

まず医師はマニュアル位置決め機構を利用しておおよ その血管位置へプローブをセットする. その後自動位置決 めソフトウェアを利用して血管の長軸断面画像を描出し, 安静時の血管径を求める. 駆血解除後約 3 分間にわたりほ ぼリアルタイムで血管径を計測する.この際位置ずれが生 じた場合，再度位置決めが可能である。

プローブ位置決めのための情報としては, 取得された超 音波画像を用いる. プローブを回転及び並進方向へ微小量 だけ動かした画像群を取得した後, 画像から求まる特徵值 が最も大きくなるような位置へプローブの位置決めを自 動的におこなう(Fig. 4).

\section{3. 実酫及び結果}

3.1. 自動位置決めソフトウェア評価実験

血管ファントムモデル及びヒト上腕動脈に対して長軸 断面へのプローブ位置決め実験を行った。測定は各々 40 回とし, 位置決め後の径を測定した. どちらの場合も測定 結果の標準偏差が小さくなり, 測定の精密さが向上した. ヒト測定においては著者による測定值との間に若干ずれ がみられた(Table 1).これは血管壁の認識位置に違いが生 じたためと考えられる。

\section{2.被験者での FMD 測定実験}

本研究で開発したシステムのプローブ自動位置決め及 び血管径算出を利用して 3 名の健常者を被験者とし た\%FMD 測定を試みた. 被験者の情報及び測定結果を表 にまとめた(Table 2). また, 測定おける血管径を時閒軸に 対してプロットしたものを示す(Fig. 5, 6).

\section{4. 考察と結論}

3.1 より再現性の高い自動プローブ位置決めが示された また, 同一被験者のヒト上腕動脈に対して, プローブ位置 決めにおける再現性を医師測定の場合と比較したところ, 標準偏差で約 60\%低減を実現した (Fig. 7).

3.2 の結果より, システムを用いた\%FMD 測定の可能性 が示された. 測定 1〜3 では同一被験者による再現性の評 価が可能である. 測定 1 と 3 では近い\%FMD が得られた 一方で, 測定 2 に関してはプローブ位置決めが最適におこ なわれなかったため計測失敗となった. 測定 3〜5におい ては，異なる被験者でも\%FMD が測定可能であることが 示されたものの, 一部值にばらつきがみられた。 \% FDD の值は, 測定 1 では 20 代健常男性の平均值である 10.60

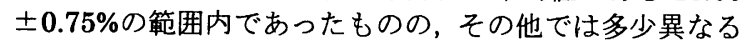
值となった.

\%FMD 值に再現性が見られなかった一因として，駆血 解除後の腕の動きが考えられる. 駆血帯解除時や患者が体 勢を変えることにより腕が動いてしまい, 結果として長軸 画像断面が変化した. 解決法としては, より強固な腕固定 器具の開発や, より柔軟な位置決めアルゴリズムの開発が 望まれる。

測定時間に関しては, 大幅に短縮が可能であった. 従来 医師が約 3 分間の画像群に対してフレーム毎に血管径を 計測する必要があり, 数十分の時間を要していた. システ ムの利用により，ほぼリアルタイムでの径測定が可能とな り, 拡張反応終了と同時に\%FMD 值を得ることが可能と なった。

\section{5. 結論}

自動血管径測定及びプローブ位置決めを高再現性でお こなうことが可能となり，検查時間の短縮が実現できた． また自動\%FMD 測定への可能性を示した.

\section{6. 参考文献}

1)Mary C. Correti, et al. Guidelines for the Ultrasound Assessment of Endothelial Dependent Flow-Mediated Vosodilation of the Brachial Artery. Journal of the American College of Cardiology, 2002; 39(2):257-265. 2)橋本正良．超音波による内皮機能診断．臨床医．1998; 24(5): 789-791.

Table 1 Data summary (3.1)

\begin{tabular}{c|ccc}
\hline & Ave.(mm) & SD(mm) & Actual (mm) \\
\hline Model & 4.01 & 0.056 & 4.0 \\
Artery & 3.56 & 0.059 & $3.7(※)$ \\
\hline
\end{tabular}

(※) measured by author without FMD-AMS

Table 2 Subject information and result (3.2)

\begin{tabular}{c|ccccc}
\hline No. & 1 & 2 & 3 & 4 & 5 \\
\hline Subject & A & A & A & B & C \\
Age & 24 & 24 & 24 & 25 & 24 \\
Sex & M & M & M & M & F \\
At rest(mm) & 3.67 & 3.67 & 3.67 & 4.11 & 3.65 \\
Max(mm) & 4.07 & $\cdots$ & 3.96 & 4.7 & $4.1(※)$ \\
\%FMD(\%) & 10.8 & $\cdots$ & 7.9 & 14.3 & 12.3 \\
\hline \multicolumn{2}{r}{ (※)ignore remarkable errors } &
\end{tabular}

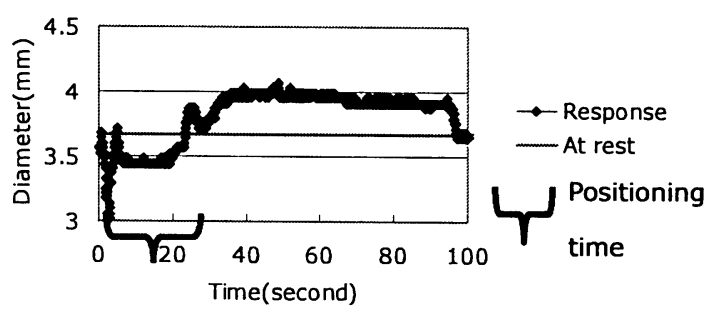

Fig.5 No. 1 (subject A)

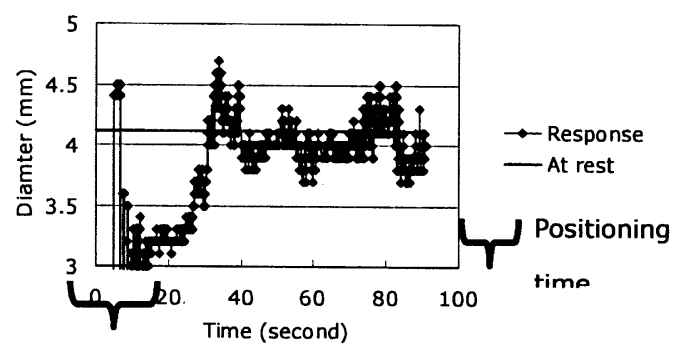

Fig. 6 No. 4 (subject B)

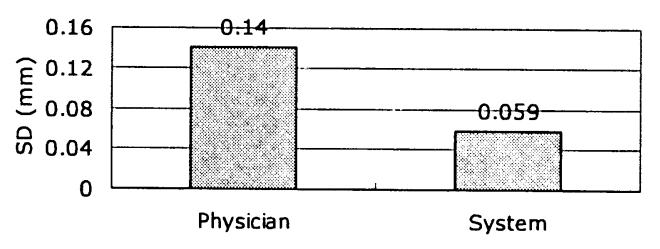

Fig. $7 \mathrm{SD}$ comparison 